and the language of indigenous peoples. It is revealed that the current tendency in educational policy is transition from assimilation policy to integration policy. It is shown that modern education of indigenous peoples in the USA and Canada is based on the principles of multiculturalism, democracy, humanism, nationalist approach, taking into account educational needs and labor market needs.

Key words: indigenous peoples, indigenous education, legislation, boarding schools for indigenous children, educational policy of assimilation, educational integration policy, USA, Canada.

УдК 371.315.6:51

Валентина Орєхова

ДВНЗ «Донбаський державний педагогічний університет»

ORCIDID 0000-0002-7909-1077

DOI 10.24139/2312-5993/2019.05/057-068

\title{
ТРАНСМЕДІЙНІ НАВИЧКИ У ПРОФЕСІЙНІЙ МИСТЕЦЬКІЙ ОСВІТІ: АНАЛІЗ ЗАРУБІЖНОГО ДОСВІДУ
}

Метою статті $\epsilon$ визначення комплексу трансмедійних навичок майбутніх учителів музичного мистецтва на основі аналізу зарубіжного наукового досвіду. Автор розглядає теоретичне поняття трансмедійної грамотності як такої, що забезпечує створення, впровадження й використання трансмедійних продуктів в освітній мистецькій діяльності під час формування професійної компетентності майбутніх учителів музичного мистецтва. Методи дослідження: аналіз зарубіжнихнаукових джерел, індукція і узагальнення отриманих даних, класифікація трансмедійних навичок. Вивчення зарубіжного наукового доробку (праць С. Лівінгстона, Д. Букінгема, Дж. Хартлі, А. Сколарі, Г.Дженкінса та ін.) дозволило виокремити у складі трансмедійної компетентності майбутніх учителів музичного мистецтва п'ять груп навичок: технічні, оцінно-рефлексивні, організаційні, комунікативні, безпека в Інтернеті.

Ключові слова: трансмедіа, трансмедійна компетентність, трансмедійна грамотність, трансмедійні навички, професійна мистецька освіта, майбутні вчителі музичного мистецтва.

Постановка проблеми. Соціальне життя молоді побудовано навкруг цифрових технологій - від соціальних мереж до мобільних телефонів - і суттєво відрізняється від усталених освітніх практик. Інтегрування сучасних цифрових технологій та поява нових форм ЗМІ сприяли оновленню концептуальних підходів в освіті. Наразі набуває поширення поняття трансмедійної компетентності в професійній освітній діяльності, зокрема в мистецькій освіті.

Трансмедійна технологія змінила й розширила як маркетингові, соціальні та комунікативні сфери існування соціуму, так і креативні технології розвитку мистецької професійної освіти. Наразі на часі вести мову про формування трансмедійної грамотності, яка виходить за межі традиційної медіаграмотності й виводить на новий рівень освітні практики. У даному дослідженні 
нас цікавить трансмедійна грамотність у складі відповідної компетентності, володіння якою забезпечує створення, впровадження і використання трансмедійних продуктів у освітній мистецькій діяльності під час формування професійної компетентності майбутніх учителів музичного мистецтва.

Аналіз актуальних досліджень. Про трансмедійну технологію й відповідні навички ми дізналися із зарубіжної літератури. У вітчизняному науковому обігу поняття «трансмедіа» (transmedia) та похідні від нього категорії «трансмедійної кометентності» (transmedia competence), «трансмедійної грамотності» (transmedia literacy) та ін. з'явилися лише в останні роки. Тому доречно оглянути зарубіжні наукові джерела.

Необхідність дослідження медійної грамотності вперше була висловлена у 2004 році С. Лівінгстоном (S. Livingstone) «як потреба визначення нових навичок і практик сучасних медіакористувачів у якості привласнення IKT у їх повсякденному житті...» (Livingstone, 2004, с. 11). Згодом у 2006 році Д. Букінгем (D. Buckingham) продовжував актуалізувати питання формування сучасних навичок у сфері медіаграмотності молоді в науковій праці «Вивчення цифрової грамотності. Що молоді люди повинні знати про цифрові медіа?» («Defining digital literacy. What do young people need to know about digital media?») (Buckingham, 2006). На його думку, зміст поняття медіаграмотності має коригуватися використанням цифрових медіа і наближається до поняття «цифрової грамотності» (digital literacy).

У 2009 р. Дж. Хартлі (J.Hartley) окреслив проблему інтуїтивного володіння підлітками технологіями використання різних медіаплатформ у повсякденному житті: «Підлітки, вочевидь, не розглядають комп'ютери як технологію. Начебто вони володіють вродженою здатність до текстових повідомлень, використання леєрів iPod, ігор і реалізації багатьох задач на декількох платформах. Вони можуть ділитися історією свого життя на Facebook, розважати один одного на YouTube, філософствувати в блогосфері, сприяти знанням у Вікіпедії, створювати передові мистецтва на Flickr» (Hartley, 2009). На думку науковця, усі ці «вроджені здібності», набуті поза школою в процесі соціальних і технологічних змін, призвели до переосмислення значення навчання впродовж життя i по всьому світу, принципів співучасті під час набуття досвіду і фактично сприяли перегляду концепції медіаграмотності. У цьому контексті А. Сколарі (A. Scolari) презентує ідею «трансмедійної грамотності» як перехід від традиційної медіаграмотності (викладання критичних навичок 3МІ в школі) до «аналізу практик спільних культур, вмісту, створеного молоддю, та неформального навчання стратегії їх використання всередині формальної системи освіти» 
(Scolari, 2016; 2018). Ідею необхідності формування трансмедійної грамотності в педагогічній діяльності активно підтримують інші зарубіжні науковці: Г.Дженкінс (Jenkins, 2006), Дж. Феррес-Прат (Ferrés-Prat, 2014), Л. Тріпп (Tripp, 2010), Дж. Сефтон-Грін (Sefton-Green, 2013) та ін.

у вітчизняних дослідженнях поняття трансмедійної компетентності майже не розглянуто, хоча технологія трансмедіа поступово займає все вагоміше місце в сучасній культурі, мистецтві, медіа засобах, збагачує традиційну освіту інноваційними формами й методами. На нашу думку, питання формування трансмедійної компетентності у професійній освіті $\epsilon$ надзвичайно важливим, потребує усвідомлення власне поняття «трансмедіа», актуальним $\epsilon$ аналіз та систематизація трансмедійних навичок, що забезпечить теоретичні підвалини формування компетентнісного кола майбутніх фахівців мистецької освітньої галузі, зокрема учителів музичного мистецтва.

Метою статті $\epsilon$ визначення комплексу трансмедійних навичок майбутніх учителів музичного мистецтва на основі аналізу зарубіжного наукового досвіду.

Методи дослідження. Під час вивчення специфіки понять «трансмедіа», «трансмедійна компетентність», «трансмедійна грамотність» були використані ключові методи наукового пізнання: аналіз наукової літератури та інтернет-джерел із досліджуваної проблеми, індукція й узагальнення отриманих даних, класифікація трансмедійних навичок за певними критеріями.

Методологічною основою вивчення трансмедійної компетентності було обрано компетентністний підхід як такий, що орієнтує на досягнення практичних результатів та забезпечує умови для професійної підготовки майбутніх учителів мистецьких дисциплін, зокрема музичного мистецтва.

Виклад основного матеріалу. Сьогодні молодь $€$ активним учасником цифрового Всесвіту: соціальних медіа, мережевих об'єднань, електронного навчання тощо. Це підтверджує факт наявності низки користувацьких цифрових навичок. Проте вони (цифрові навички) дещо відрізняються від трансмедійних, які необхідні в цифровому сьогоденні для отримання якісної професійної мистецької освіти. Трансмедійні навички забезпечують доступ і вільне використання широкого кола мистецького контенту, що постійно оновлюється і трансформується, необхідного майбутнім учителям музичного мистецтва для успішного навчання й подальшої професійної діяльності.

Проте наявний комплекс користувацьких навичок медіа грамотності (навігація, пошук, інтерпретація змісту і критичне оцінювання тощо) вже не 
забезпечує отримання глибоких знань та формування необхідних умінь. Тож актуальності набуває поняття «трансмедійної компетентності», у складі якої виокремлюється низка навичок, пов'язаних із виробництвом та спільним використанням інтерактивного контенту. Для того, щоб визначити необхідні трансмедійні навички в структурі професійної компетентності майбутніх учителів мистецтва, звернемося до зарубіжного досвіду.

Великий внесок у дослідженні трансмедійної технології зроблений Г. Дженкінсом, який розглядає трансмедійну розповідь як специфічну форму подання інформації через вербальну і невербальну комунікації різними медіазасобами, де окремі історії доповнюють одна одну 3 метою формування цілісного інформаційного Всесвіту. Серед основних рис трансмедійного продукту науковець виокремлював такі: швидке поширення інформації; розширення й занурення через гіперпосилання; серійність і тривалість (незавершеність) інформаційного сюжету; суб'єктивність поданої інформації через багатовимірність гіперпосилань; іммерсивність, створення ефекту присутності шляхом використання новітніх технологій і різноформатного медіаконтенту; активний взаємозв'язок автора (авторів) трансмедійного продукту з аудиторією (Jenkins, 2006, с. 23).

У своєму дослідження Г. Дженкінс до складу трансмедійних навичок відносить відтворення, судження (аналіз), трансмедійні навігації, мережеві та комунікативні складові (Jenkins, 2006). Навички трансмедіа варіюють від процесів вирішення проблем у відеоіграх до виробництва та обміну контентом у контексті веб-платформ та соціальних мереж; створення, виробництво, обмін і критичне споживання наративного змісту також $\epsilon$ частиною трансмедійної компетентності (Scolari et al., 2018).

Л.Флемінг вважає, що використання новітніх інформаційних технологій, зокрема трансмедіа, привнесе наявну користь в освітній процес (Fleming, 2013, с. 371). Науковиця стверджує, що педагогічна практика використання трансмедійної технології відображає сутність навчання XXI століття і дає певні переконливі можливості для якісного здобуття освіти. Дослідниця вбачає трансмедійну освіту в застосуванні методів розповіді в поєднанні з використанням декількох платформ для створення «захоплюючого ландшафту навчання», що поширює діапазон сприйняття освітнього досвіду і сприятиме навчанню без меж. «Навчання $з$ використанням багатьох засобів масової інформації забезпечує велику безперервність у навчанні. Кожна частина головоломки працює, щоб залучити учня» (Fleming, 2013, с. 371). Такий сучасний підхід в освіті акцентує актуальність необхідності формування трансмедійної 
компетентності й набуття трансмедійних навичок у професійній освіті, зокрема майбутніх учителів музичного мистецтва.

3 метою виявлення трансмедійних навичок, які молодь набуває в умовах неформальної освіти, було організовано проведення експериментального дослідження у восьми країнах Світу (Австралія, Колумбія, Фінляндія, Італія, Португалія, Іспанія, Великобританія та Уругвай). Дослідницький експеримент був організований за прописаними п'ятьма основними кроками (Scolari et al., 2018):

- організація експериментальної платформи на базі освітньої установи для укладання згоди навчального закладу, батьків і підлітків про поінформованість та безпеку;

- початкове анкетування для ознайомлення з соціально-культурним фоном молоді, виявлення рівня використання ЗМІ та сприйняття інформації через них;

- проведення навчальних семінарів для вивчення поведінки молоді під час трансмедіації та залучення їх до створення цифрового контенту і «геймплея»;

- поглиблені інтерв'ю з найбільш активними учасниками експерименту, аналіз медіа-щоденників для ознайомлення 3 діями й висловлюваннями щодо медіаконтенту, соціальних мереж та відеоігор;

- он-лайн-спостереження за улюбленими веб-сайтами, он-лайнспільнотами та ін. (netgraphy).

На початковому етапі експерименту зарубіжними дослідниками було проаналізовано і взято до уваги низку таксономій: традиційна таксономія Б. Блума (Bloom, 1956); Л. Андерсона и Д. Красвола (Anderson \& Krathwohl, 2001), Дж. Феррес-Прата і А. Піскітеллі (Ferrés-Prat \& Piscitelli, 2012), Г. Дженкінса (Jenkins, 2006). За результатами проведеного експерименту і на основі аналізу попередніх таксономій командою експериментальних дослідників сформовано великий перелік (близько двохсот) трансмедійних навичок, які обертаються навкруг різноформатного контенту, технологій і процесів та детально відтворюють дії, пов'язані 3 виробництвом, споживанням та розповсюдженням медіа в колі молодіжної трансмедійної культури. Згруповані навички формально класифікуються за напрямами використання і рівнем складності: від написання (для коротких оповідань) до мультимодальних проектів (для роботи з відеоконтентом); від простого (для пошуку інформації) до складного (для керування соціальними мережами та блогами й архівування змісту); від технічних (для фотографування) до критичних і етичних практик (для розпізнавання ризиків саморозкриття в 
соціальних мережах); від когнітивних (для розпізнавання й опису жанрів у різних медіа та платформах) до прагматичних установок (для вибору та споживання, виходу з контенту на основі етичних і моральних цінностей). Пропонуємо для розгляду основні угрупування трансмедійних навичок (за версією А. Сколарі і дослідницької команди).

Таблиця 1

Трансмедійні навички(за А. Сколарі та ін.) (Scolari et al., 2018).

\begin{tabular}{|c|c|c|}
\hline Назва навички & Опис & Основні вміння \\
\hline Виробнича & $\begin{array}{lr}\text { Здатність задумувати, } \\
\text { планувати, створювати, } \\
\text { редагувати } \\
\text { розміщувати ионтент } \\
\text { на козни } \\
\text { медіапдатформах }\end{array}$ & $\begin{array}{l}\text { Створення і редагування (тексти, фото, } \\
\text { малюнки, графіка, аудіо-відео контент); } \\
\text { використання (програмове забезпечення; } \\
\text { навички роботи із звуком, відео і фото } \\
\text { матеріалами, інструментами креслення } \\
\text { та проектування); } \\
\text { кодування, побудова та зміна } \\
\text { програмового і технічного забезпечення; } \\
\text { дизайнерські навички; } \\
\text { управління контентом (здатність керувати } \\
\text { різними ЗМІ через низку платформ та } \\
\text { медіа: вибирати, завантажувати та } \\
\text { розповсюджувати контент) } \\
\text { керування архівами вмісту; } \\
\text { керування розповсюдженням і обміном } \\
\text { вмісту }\end{array}$ \\
\hline $\begin{array}{l}\text { Індивідуальна } \\
\text { самоорганізація }\end{array}$ & $\begin{array}{l}\text { Здатність самостійно } \\
\text { управляти ресурсами } \\
\text { та часом; власною } \\
\text { ідентичністю, } \\
\text { почуттями та емоціями }\end{array}$ & $\begin{array}{l}\text { Самоорганізація; } \\
\text { особистісна індивідуальність; } \\
\text { управління емоційним станом }\end{array}$ \\
\hline $\begin{array}{l}\text { Соціальний } \\
\text { менеджмент }\end{array}$ & $\begin{array}{l}\text { Здатність } \\
\text { організації, } \\
\text { спілкування, керування } \\
\text { і координування }\end{array}$ & $\begin{array}{l}\text { Участь у соціальних медіа; } \\
\text { співпраця; } \\
\text { координація і керівництво; } \\
\text { здатність до навчання }\end{array}$ \\
\hline $\begin{array}{l}\text { Продуктивність } \\
\text { (дієвість, } \\
\text { активність) }\end{array}$ & $\begin{array}{l}\text { Усі види діяльності ЗМІ, } \\
\text { що використовують } \\
\text { фізичне тіло: реальні } \\
\text { життєві } \\
\text { (виконавське } \\
\text { мистецтво), віртуальні } \\
\text { сценарії (відеоігри) }\end{array}$ & $\begin{array}{l}\text { Гра у відеоігри; } \\
\text { порушення правила; } \\
\text { дотримання правила }\end{array}$ \\
\hline $\begin{array}{l}\text { Засоби } \\
\text { технології }\end{array}$ & $\begin{array}{l}\text { Володіння соціально- } \\
\text { політичною ситуацією, } \\
\text { технічними } \\
\text { комунікаційними } \\
\text { складовими, розуміння } \\
\text { особливостей роботи } \\
\text { ЗМІ }\end{array}$ & $\begin{array}{l}\text { Прийняття і опис інформації; } \\
\text { порівняння і аналіз інформацій; } \\
\text { оцінка й відображення; } \\
\text { застосування знань і організація заходів }\end{array}$ \\
\hline
\end{tabular}


Продовження Таблиці 1

\begin{tabular}{|c|c|c|c|}
\hline $\begin{array}{l}\text { Розповідь } \\
\text { естетика }\end{array}$ & $i$ & $\begin{array}{l}\text { Навички, пов'язані з } \\
\text { інтерпретацією історій } \\
\text { та оповідальних } \\
\text { структур, заглиблення в } \\
\text { побудову розповіді } \\
\text { через аналіз та оцінку } \\
\text { жанрів, персонажів, } \\
\text { естетичних } \\
\text { особливостей; } \\
\text { здатність } \\
\text { реконструювати } \\
\text { трансмедійний контент }\end{array}$ & $\begin{array}{l}\text { Інтерпретація; } \\
\text { визначення ключових моментів і опис; } \\
\text { порівняння; } \\
\text { оцінювання і відображення; } \\
\text { застосування знань }\end{array}$ \\
\hline $\begin{array}{l}\text { Ідеологія } \\
\text { етика }\end{array}$ & & $\begin{array}{l}\text { Виявлення та аналіз } \\
\text { медіа репрезентацій } \\
\text { стереотипів (з точки } \\
\text { зору статі, культури, } \\
\text { релігії, раси тощо) та } \\
\text { етичних } \\
\text { пов'язаних } \\
\text { авторським правом } \\
\text { шахрайством }\end{array}$ & $\begin{array}{l}\text { Визнання і опис; } \\
\text { оцінка і відображення; } \\
\text { вживання заходів і застосування знань }\end{array}$ \\
\hline $\begin{array}{l}\text { Запобігання } \\
\text { ризикам }\end{array}$ & & $\begin{array}{l}\text { Навички, пов'язані } \\
\text { пізнанням і вживанням } \\
\text { заходів щодо } \\
\text { конфіденційності та } \\
\text { безпеки у зМІ (зокрема } \\
\text { в соціальних мережах); } \\
\text { усвідомлення своїх } \\
\text { «трансмедійних } \\
\text { навичок», як комплексу } \\
\text { компетенцій, } \\
\text { пов'язаних } \\
\text { виробництвом } \\
\text { цифрового } \\
\text { інтерактивного медіа, } \\
\text { обміну та споживання } \\
\text { власної ідентичності; } \\
\text { можливих залежностей } \\
\text { відмедіа }\end{array}$ & $\begin{array}{l}\text { Визнання і прийняття; } \\
\text { оцінювання і відображення; } \\
\text { застосування знань і вживання заходів }\end{array}$ \\
\hline
\end{tabular}

Отже, дослідницька група представила всебічний опис основних трансмедійних навичок, якими може володіти молодь. Результати дослідження охоплюють суттєвий перелік: від конкретно технологічних до навичок, пов'язаних із ідеологічними та естетичними проявами. 3 даною диференціацією трансмедійних навичок не можна погодитися цілком і повністю, наприклад, «запобігання ризикам» - це фактично навички 
безпечної роботи в Інтернет-мережі, дотримання авторських прав та принципів конфіденційності. До того ж слід було би виокремити навички рефлексії щодо усвідомлення своїх "трансмедійних навичок», як комплексу умінь, пов'язаних із виробництвом цифрового інтерактивного медіа, обміну та споживання власної ідентичності; можливих залежностей від медіа.

Вочевидь, студенти мистецьких спеціальностей мають неоднаковий рівень володіння такими навичками. Більш того, у контексті швидкої зміни медіасередовища і культурної практики, питання трансмедійної компетентності набуває динамічності і постійної трансформації. Д. Бойд відзначив: «Ані підлітки, ані дорослі не можуть залишатися монолітними (по відношенню до трансмедійної грамотності) і немає ніякого магічного зв'язку між віком і навичками. Будь-то в закладі освіти чи в неформальній обстановці, молоді потрібні умови для розвитку навичок і знань для ефективної взаємодії з сучасними технологіями. Трансмедійна компетентність потребує важкої роботи, незалежно від віку» (Boyd, 2014, с. 338).

\section{Висновки та перспективи подальших наукових розвідок.} Проаналізовані нами результати дослідження А.Сколарі та ін., наведені показники активних медіакористувачів різних спеціальностей та видів діяльності, аналіз зарубіжних наукових розвідок у галузі трансмедійної грамотності дозволили звернути увагу на низку ключових положень щодо володіння трансмедійними навичками майбутніми вчителями мистецьких дисциплін, зокрема музичного мистецтва.

1. Критичне сприйняття наявного та створюваного контенту. Вважається, що рівень володіння навичками продуктивного спрямування дещо вищий, ніж ідеологічними й естетичними. Проте мистецька і викладацька професійна спрямованість вимагає більш пильної уваги щодо просування критичного підходу до створення, поширення й користування медіа.

2. Трансорормачія трансмедійних навичок як результат постійного розвитку медіасередовища. Деякі навички (переважно технічного характеру) залежать від постійних технологічних змін, тому їх класифікація вимагає періодичного оновлення і корекції відносно технічних і технологічних інновацій медіасередовища.

3. Безпека в Інтернеті. Одним із аспектів, який викликає постійне занепокоєння, $€$ питання дотримання правил безпечного поводження в Інтернеті. Хоча дослідниками було доведено, що навички запобігання ризикам наявні в молоді, це питання потребує постійного контролю і ситуативної корекції, оскільки охоплює широке коло ситуацій від самих базових (розпізнання і опис мір безпеки та конфіденційності) до більш 
складних (організація розміщення контентів із урахуванням питань безпеки і конфіденційності).

Аналіз результатів зарубіжних досліджень трансмедійної компетентності, урахування специфічних особливостей професійної підготовки фахівців у галузі мистецької освіти дозволили виокремити п'ять груп трансмедійних навичок, які забезпечують формування відповідної компетентності майбутніх учителів музичного мистецтва:

1. Технічні навички, необхідні для роботи з медійним контентом. Серед них: навички створення, редагування й розповсюдження контенту; навички роботи з текстом, аудіо, відеоматеріалами, зображеннями, графіками, таблицями тощо; адаптування контенту для різних медіа середовищ; навички створення мультимедійного продукту; володіння необхідним програмовим забезпеченням.

2. Очінно-рефлексивні навички, що забезпечують дотримання загальноприйнятих естетичних вимог щодо якості цифрового контенту, використання культурних цінностей та вирішення етичних питань; усвідомлення користувачем ступеню сформованості «трансмедійних навичок», пов'язаних із виробництвом цифрового інтерактивного медіа, та можливих залежностей від медіа.

3. Організаційні навички, що забезпечують організацію спілкування, керування і координування: створення багатовимірного інформаційного середовища за допомогою різних медіа каналів; залучення користувачів до співпраці; координація й керівництво; здатність до навчання.

4. Комунікативні навички, які сприяють коректному спілкуванню, інтерпретації історій та оповідальних структур (storytelling), заглибленню до побудови трансмедійної розповіді через аналіз та оцінку жанрів, персонажів, естетичних особливостей; здатність реконструювати трансмедійний контент: створення мікроісторії і мікроситуацій, що розгортаються; групова робота.

5. Навички безпечного поводження в Інтернеті: дотримання конфіденційності в соціальних мережах; усвідомлення рівня залежності від Інтернету; володіння необхідним технічним забезпеченням щодо створення безпечних умов користування в Інтернеті; дотримання норм етикету й повага авторських прав.

Комплекс трансмедійних навичок у складі трансмедійної компетентності майбутніх учителів музичного мистецтва можна унаочнити з допомогою інфографіки (рис. 1). 


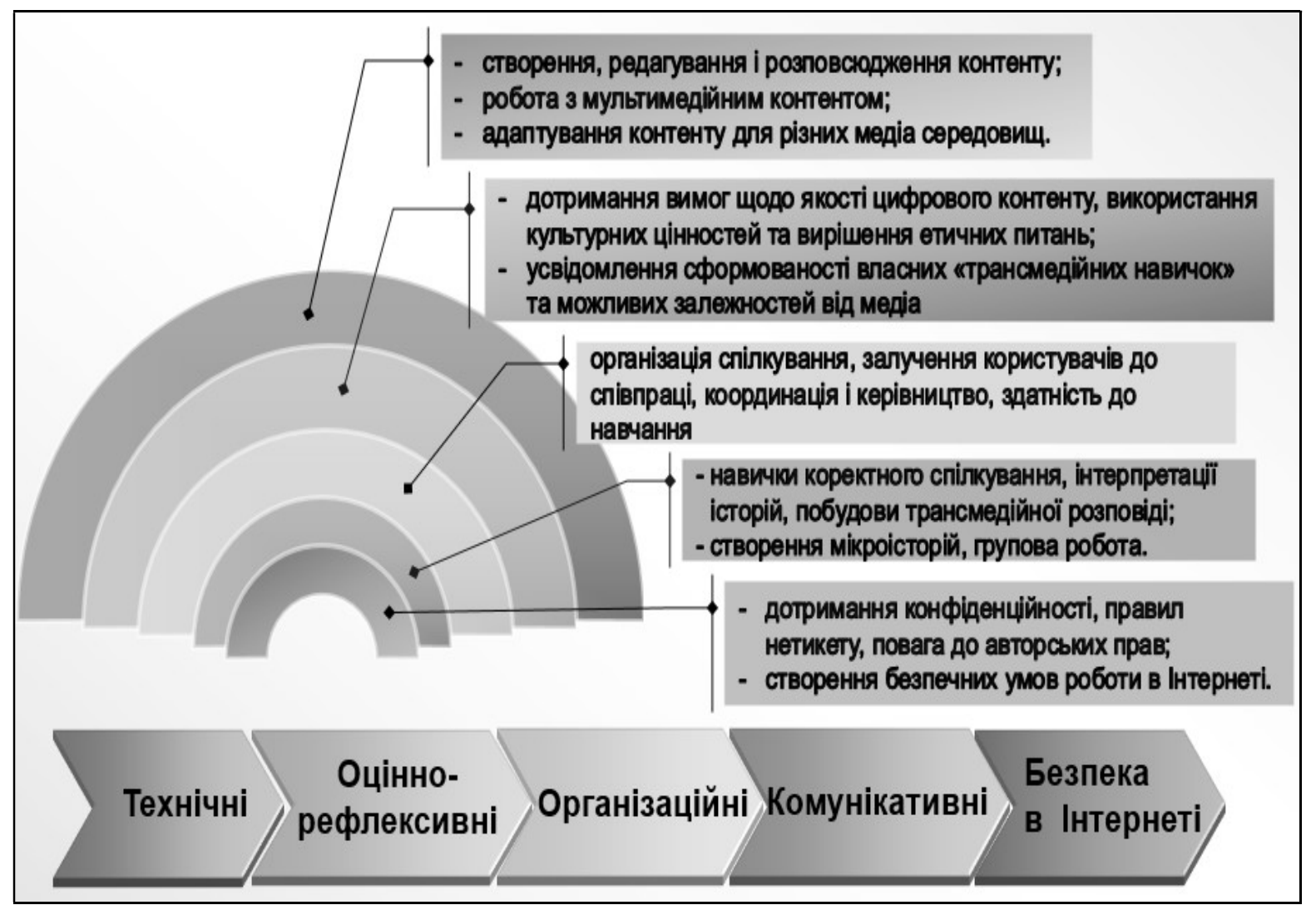

Рис. 1. Групи трансмедійних навичок майбутніх учителів музичного мистецтва

Отже, вивчення й класифікація трансмедійних навичок майбутніх учителів музичного мистецтва, подальше розроблення форм і методів їх формування $\epsilon$ необхідною передумовою успішної професійної підготовки фахівців, зокрема розвитку професійної компетентності музикантівпедагогів. Перспективи подальшого дослідження вбачаємо в упровадженні засобів трансмедійних технологій у традиційну та неформальну мистецьку освіту.

\section{ЛITEPATУPA}

Anderson, L.; Krathwohl, D. (Eds.) (2001). A taxonomy for learning, teaching, and assessing: a revision of Bloom's taxonomy of educational objectives. New York, USA: Longman.

Bloom, B. (Ed.) (1956). Taxonomy of educational objectives: classification of educational goals. Handbook I: Cognitive domain. New York and Toronto, USA: Longmans, Green.

Boyd, D. (2014). It's complicated: the social lives of networked teens. London/New Haven, USA: Yale University Press.

Buckingham, D. (2006). Defining digital literacy. What do young people need to know about digital media? Digital competence. Nordic journal of digital literacy, 1, 263-276. Retrieved from: https://goo.gl/58fXPr.

Ferrés-Prat, J. (2014). Las pantallas y el cerebro emocional. Bacelona, Spain: Gedisa.

Ferrés-Prat, J., Piscitelli, A. (2012). Media competence. Articulated proposal of dimensions and indicators. Comunicar, 38, 75-82. Retrieved from: https://doi.org/10.3916/C382012-02-08. 
Fleming, L. (2013). Expanding learning opportunities with transmedia practices: Inanimate Alice as an Exemplar. Journal of Media Literacy Education, 5, 370-377. Retrieved from: https://digitalcommons.uri.edu/cgi/viewcontent.cgi?article=1124\&context=jmle.

Hartley, J. (2009). Uses of YouTube. Digital literacy andthe growth of knowledge. In: Burgess, J., Green, J. (Eds.), YouTube: Online video and participatory culture. Cambridge, UK: Polity, 126-143.

Jenkins, H., Clinton, K., Purushotma, R., Robison, A., Weigel, M. (2006). Confronting the challenges of participatory culture: media education for the 21st Century. Chicago (IL): MacArthur Foundation. Retrieved https://www.macfound.org/media/article pdfs/JENKINS WHITE PAPER.PDF

Jenkins, H. (2006). Convergence culture. Where old an new media collide. New York, USA: New York University Press. Retrieved from: https://goo.gl/AvrMUA.

Livingstone, S. (2004). Media literacy and the challenge of new information and communication technologies. The communication review, Vol. 7, no 1, 3-14. Retrieved from: http://eprints.Ise.ac.uk/1017.

Masanet, M.-J. (2016). Pervivencia de los estereotipos de género en los hábitos de consumo mediático de losadolescentes: drama para las chicas y humor para los chicos. Cuadernos.info, Vol. 39, 39-53. Retrieved from: https://doi.org/10.7764/cdi.39.1027.

Scolari, A. (2016). Alfabetismo transmedia. Estrategias de aprendizaje informal y competencias mediáticas en lanueva ecología de la comunicación. Telos, 103, 12-23.

Scolari, A. (2018). Teens, media and collaborativecultures: exploiting teens' transmedia skills in the classroom. Transmedia Literacy H2020 Research and Innovation, Barcelona. Retrieved from: http://transmedialiteracy.upf.edu/sites/default/files/files/TL Teens en.pdf.

Scolari, A. Masanet, M.-J.; Guerrero-Pico, M.; Establés, M.-J. (2018). Transmedia literacy in then we media ecology: teens' transmedia skills and informal learning strategies. $E I$ profesional de la información, Vol. 27, no 4, 801-812. Retrieved from: https://doi.org/10.3145/epi.2018.jul.09.

Sefton-Green, J. (2013). Learning at not-school: Areview for study, theory and advocacy for education innon-formal settings. Cambridge, USA: MIT Press.

Tripp, L. (2010). Hanging out, messing around, and geeking out: Kids living and learning with new media. Cambridge, USA: The MIT Press, 243-293.

\section{PEЗЮME}

Орехова Валентина. Трансмедийные навыки в профессиональном художественном образовании: анализ зарубежного опыта.

Статья посвящена вопросу формирования трансмедийной компетентности будущих учителей музыкального искусства. Трансмедийную грамотность автор рассматривает как средство создания и использования трансмедийних продуктов в профрессиональном художественном образовании. Для разностороннего рассмотрения данного вопроса использовались методы научного познания: анализ зарубежного опыта, индукция и обобщение полученных знаний, классификация трансмедийних навыков по направлениям. В составе трансмедийной компетентности автор выделяет такие группы навыков: технического производства, культурноэстетические, организационные, коммуникативные, безопасность в Интернете. Также комплекс трансмедийних навыков представлен в виде инфографики.

Ключевые слова: трансмедийная компетентность, трансмедийные навыки, профессиональная подготовка будущего учителя музыкального искусства. 


\section{SUMMARY}

OriekhovaValentyna. Transmediate skills in professional art education: analysis of external experience.

The article is devoted to the formation of transmedia competence of future music art teachers. The author considers transmedia literacy as a way to create and use transmedia products in the educational art process. The purpose of the article is to define a complex of transmedia skills for the formation of transmedia competence as a necessary component of contemporary artistic education, in particular training of future musical art teachers.

For versatile consideration of this issue, the methods of scientific research were used: analysis of foreign experience, induction and generalization of the knowledge gained, classification of transmedia skills in areas. The methodological basis for studying transmedia competence was the choice of a competence approach that creates the conditions for the professional education of future musical art teachers.

Foreign scholars actively developed the idea of transmedia literacy formation in pedagogical activity: S. Livingstone, D. Buckingham, J. Hartley, A. Scolari, H. Jenkins, J. FerrésPrat, L. Tripp, J, Sefton-Green and others.

Based on the results of foreign studies and taking into account the specifics of vocational art education, a Map of the main transmedia skills that form the transmedia competence of future music art teachers is created. As part of transmedia competence, the author identifies the following skill groups: technical production, cultural and aesthetic, organizational, communication, security on the Internet. The research result is the infographics of transmedia skills complex that form the transmedia competence of future musical art teachers. The author stresses that creation of multimedia content and active involvement of students in the transmedia skills use is one of the key aspects of transmedia competences formation as part of the professional competences of future musical art teachers. A transmedia skills map can be a useful tool for the development of didactic activities in professional artistic education. Special attention should be paid to the strategy of transmedia competence formation both in the circle of the actual educational trajectory and in format of informal education.

Key words: transmedia competence, transmedia skills, professional training of the future musical art teacher.

Удк 796.071.4:341.48(436)

Ольга Романчук

Дрогобицький державний педагогічний

університет ім. І. Франка

ORCID ID 0000-0001-8215-9741

DOI 10.24139/2312-5993/2019.05/068-081

\section{ОРГАНІЗАЦІЙНІ АСПЕКТИ ПРОФЕСІЙНОЇ ПІДГОТОВКИ МАГІСТРІВ СПЕЦІАЛЬНОСТІ «РУХ І СПОРТ» В АВСТРІї}

Стаття присвячена вивченню особливостей професійної підготовки магістрів в Австрії. Мета статmі полягає в аналізі особливостей професійної підготовки магістрів спеціальності «Рух і спорт» в Австрії. Визначено, що ключова мета вищої педагогічної освіти в галузі спорту і фізичної культури в Австрії полягає в підготовці висококваліфікованих фрахівців для всіх ланок системи спортивнофізкультурної освіти. Програма професійної підготовки магістрів зі спеціальності «Рух і спорт» австрійських закладів вищої освіти охоплює три приблизно однакові за 